\title{
Amurru Göçleri ve Amurruların Eski Önasya Tarihindeki Rolleri
}

\author{
Migrations of Amorites And Their Roles in \\ History of Ancient Fore Asia
}

\section{Cemil BÜLBÜL ${ }^{*}$}

\section{$\ddot{O} z$}

Bilindiği üzere, Samî Göçlerden biri olan Amurru göçlerinin Eskiçağ tarihinde oynadığı rol inkâr edilemez. Çünkü bu göçler sonucundadır ki, Önasya toplumları gerçek hüviyetlerine kavuşmuşlardır.

MÖ. 3. Binyllın sonları ile MÖ. 2. Binyllın başlarında cereyan eden Amurru (Martu) göçleri sonucunda III. Ur Sülalesi yıkılmış ve Mezopotamya'da tüm siyasal güç Samî Amurrular'ın eline geçmiştir.

Sümerce Martu kelimesi "Batı” anlamına gelmektedir. Samiler ise Martular'a Amurru diyorlardl. Öyle anlaşıllyor ki, bizim bugün bedevi yani göçebe dediğimiz çöllerde yaşayan kabilelere Sümerler, "batıdan gelenler" anlamına "Martular" ismini vermişlerdi.

Klsa zamanda Mezopotamya sitelerine yayllan Amurrular ya da Martular çok geçmeden Mezopotamya'yı tam anlamıyla Samî bir hüviyete büründürmüşlerdir. Öyle ki, Amurrulu kabilelerin kurduğu devletler her tarafi kaplarken, Sümer dili de yerini Akkad diline ve yazısına terk etmiştir. Çünkü Amurrular da kendilerinden önce var olan kültürü tamamen benimsemişler ve atalarl Akkadlar gibi Akkadça konuşup, Akkad dilinde yazmışlardı. Amurru dili resmi kayıtlarda hiç kullanılmamıştı.

Anahtar Kelimeler: Amurru, Martu, Sami, Önasya, Mezopotamya.

\footnotetext{
* Dr. Kilis 7 Aralık Üniversitesi Fen-Edebiyat Fakültesi Tarih Bölümü, Kilis, cemilbulbul@kilis.edu.tr.
} 


\section{Abstract}

As known, the role of the Amorite migrations which is one of the migrations of Semitic tribes can not be denied in ancient history. Because, as a result of these migrations societies in Ancient Fore Asia gained their real identities.

At the end of the Migrations which occured between the ends of the Third Millenium and the beginnings of the Second Millenium B.C. The Third Ur Dynasty was collapsed and the whole political power was seized by Semitic Amorites.

The word "Martu” means "West" in Sumerian language. However the Semitic tribes called the Martu as "Amorites". As it is understood, Sumerians named the tribes living in deserts as "Martu" meaning "coming from the North" whom we call them Bedouins or Nomads ics today.

The Amorites or the Martu scattering around the Mesopotamian sites in a very short time made the Mesopotamia wrap in a totally Semitic identity soon. Moreover, as the states established by Amorites tribes were covering all over the place, Sumerian language left its place to Akkadian language and writing. This is because the Amorites took the culture existing before them as granted and their ancestors spoke and wrote in Akkadian language like the Akkadians. Amorite language had never been used in official records.

Key Words: Amorite, Martu, Semitic, Fore Asia, Mesopotamia.

\section{Giriş}

Samî göçlerin ikinci aşamasını oluşturan ve MÖ. 3. Binyılın sonları ile 2. Binyılın başlarında cereyan eden Amurru (Martu) Göçleri’ni kaynakların ışı̆̆ında, tüm ayrıntılarıyla ele almaya çalışacağız. Amurrular'ın Mezopotamya'nın siyasi ve kültürel tarihine ne gibi katkılarda bulunduğu ve her şeyden önemlisi Amurrular'ın kimliği üzerine ileri sürülen görüşleri burada tartışmaya açacağız.

Elbette ki bir ülkenin tarihini anlamanın ve anlatmanın en iyi yolu, ilk aşamada o ülkenin coğrafi özelliklerini iyi kavramaktan geçer. İşte bu yüzdendir ki, biz de çalışmamıza Yakındoğu ve Mezopotamya'nın coğrafi konumu'nu ele alarak başlayacağız.

\section{Yakın Doğu ve Mezopotamya'nın Coğrafi Konumu}

Eski Doğu'nun üç büyük medeniyet merkezinden biri olan Mezopotamya, Yunanca'da "iki nehir arası" anlamına gelmektedir. Eskiçağ tarihinde çok önemli bir role sahip olan Mezopotamya, fiziki şartları yönüyle, Toros dağlarından İran Körfezi'ne kadar uzanır ve doğal sınırlarla çevrilidir. Kuzeyden güneye doğru hafif bir meyille uzanır. Üç tarafı dağlarla 
çevrili olup; doğusunda İran dağları, batısında Akdeniz'e paralel olarak uzanan Lübnan Dağları ve Anti Lübnan dağları ile kuzeyinde Güney Anadolu dağları yer alır. Bu dağlar, çöl ile denizi birbirinden ayıran doğal bir set oluşturur. Bu yükseklikler $3000 \mathrm{~m}$ ile $2000 \mathrm{~m}$ arasında değişmektedir. Akkad Sülalesi zamanında Sedir dağları denilen Amanoslar da 2000 m'ye ulaşır.

Özetle söyleyecek olursak Mezopotamya, üç tarafı dağlarla çevrilmiş, sadece güneyden sonsuz gibi görünen Suriye ve Arabistan çöllerine açı mükemmel bir düzlüktür. ${ }^{1}$

Dicle ve Fırat gibi iki büyük nehir arasında yer alan bu verimli bölgeye, Mısırlılar da aynı manâya gelen "Naharina" adını vermişlerdir. İslami devirlerde ise Firat ve Dicle nehirleri arasında kalan bu bölge ada anlamına gelen "Cezire" olarak adlandırılmıştır.

Fakat, Mezopotamya uygarlığının temellerini atan ve buraya dışardan gelip yerleşen en eski kavim olan Sümerler ise bölgeye "Kengi" adını vermişlerdir. Mezopotamya'nın değişik yöreleri, zaman içerisinde değişik isimlerle anılmıştır. Gerçekten, bugün Hor Dalmaç diye anılan Basra Körfezi'nin kuzeybatısındaki bataklık bölgeye Yeni Sümer Devleti zamanında (MÖ. 2060-1960) "Sümer", I. Babil Sülalesi zamanında (MÖ. 1850-1550 ) "Denizeli" (Deniz İli), MÖ. 1. Biny1lda ise "Kalde” denilmekte idi. Körfezin kuzey taraflarından 34. enlem dairesine kadar olan bölgeye Sümerler zamanında Agade şehrine dayanarak "Akkad" denildiği halde ${ }^{2}$ Avrupalı araştırmacılar, bu bölgenin kuzey kesimine "Asur Ülkesi", güneydeki alüvyonlu bölgeye sirasılla "Babilonya" ve "Sümer" (Sinear), Basra Körfezi'nin doğusundaki topraklara da "Elam" adını vermişlerdi. ${ }^{3}$

Yeni Sümer Devleti olarak da adlandırılan III. Ur Sülalesi döneminde (MÖ. 2060-1960) Akkad'ın batısındaki memleketlere Batı memleketleri manâsına gelen "Martu Memleketleri", doğusuna ise, "Subartu" denildiği vesikalardan öğrenilmektedir. Dicle'nin doğusunda küçük Zap suyu ile Diyala nehri arasındaki bölgenin güney kısmına Gutium deniliyordu.Basra Körfezinin doğusundaki topraklara ise Elam deniliyordu.

Mezopotamya, verimli topraklarından dolayı sürekli istilâlara uğramıştır. Tarih boyunca değişik kavimler buraya gelip yerleşmişlerdir. Bu durum, bölgede çeşitli uygarlıkların kurulmasına sebep olmuştur. Bundan dolayı, çevrede meydana gelen değişiklik, yer isimlerine de yansıyordu.

\footnotetext{
${ }^{1}$ Kinal 1983, 10.

${ }^{2}$ Memiş 2007, 7

${ }^{3}$ Yildirım 1996, 15.
} 
Meselâ, Sümerler zamanında Sabartu denilen Dicle'nin doğu kesimine I. Babil Sülalesi zamanından itibaren Asur denilmeye başlanmıştı. I. Babil Sülalesi'nin yerini alan Kaslar ise Babil'e Karduniaş diyorlardı. Görüldügüü gibi zaman içinde Mezopotamya'nın hem sakinleri hem de topraklarının isimleri değişmiştir.

Mezopotamya, yeryüzü şekilleri bakımından karışık bir yapı arz etmektedir. Mezopotamya'nın kuzeyinin dağlık olmasına karşılık, güneyi düz bir ova görüntüsü sergiler. Fakat, Dicle ve Frrat nehirleri bu bölgeden geçmemiş olsayd1, Güney Mezopotamya Suriye Çölü'nün bir devamı niteliğinde olurdu. ${ }^{4}$

Mezopotamya'nın coğrafi şartlarına bakarak şunu söyleyebiliriz ki, Mezopotamya'da özellikle denizden uzak olan Yukarı Dicle bölgesinde kurulan hemen her devlet, siyasi birliğini sağladıktan sonra Kuzey Suriye üzerinden Akdeniz'e ulaşmayı gaye edinmiştir. Kısaca söyleyecek olursak, eskiçağ boyunca, Mezopotamya, Mısır ve Anadolu memleketleri arasındaki bütün ticari ve kültürel alışverişler burada, yani Kuzey Suriye'de meydana gelmiştir. Gerçekten, Sümer Kahramanlık çağında Uruk Kralı Gılgamış, arkadaş1 Enkidu ile birlikte Humbaba devini öldürmek için Sedir ormanlarından oluşan Amanos dağlarına gittiği gibi, Akkad devletinin kurucusu Sargon da Gümüş dağları denilen Torosları aşarak Anadolu'da Acem Höyük (Puruşhanda) şehrini zapt etmiş̦i. ${ }^{5}$

Mezopotamya'nın, Anadolu ile ticari ilişkileri, MÖ. 2. Binyıl başlarında Eski Asur Çă̆ı'nda çok hareketli bir dönemde olduğunu Kültepe kazıları ile biliyoruz. İki memleket arasındaki bu canlı münasebetler, daha sonraki Hitit devletleri zamanında devam etmiştir. ${ }^{6}$

\section{Samilerin Ana Yurdu ve Samî Göçleri’ne Genel Bakış}

Samîler'in kökeni meselesi oldukça karışıktır. Bugüne kadar bu konuda pek çok görüş ileri sürülmüştür. Günümüzde arkeolojinin vermiş olduğu veriler ve tarih araştırmaları sonunda, farklı isimlerle anılan Samî kavimler, değişik zamanlarda ve genellikle göçebe bir halde Arabistan Yarımadası'ndan gelerek Mezopotamya ve Suriye'de yaşayan kavimlerle karşılaştıktan sonra yüksek bir uygarlık meydana getirmişlerdir.

Kuzey Suriye ve Filistin'de son zamanlarda yapılan kazilardan elde edilen buluntulara göre Samîler, Mezopotamya'ya doğrudan doğruya çöl

\footnotetext{
${ }^{4}$ Memiş 2007, 8.

${ }^{5}$ Memiş 2007, 14; Şartamhari metinlerinde Sargon'un icraatları hakkında bilgi verilmektedir. Bu konuda geniş bilgi için bkz: Günbattı 1997, 131-155.

${ }^{6}$ Kinal 1983, 14.
} 
üzerinden gelmemiştir. Önce Filistin ve Suriye'deki dağlık bölgeleri takip ederek kuzeye, Münbit Hilal denilen Habur Nehri yataklarına gelmişlerdir. Buradan Firat su yolu ile Mari (Tel-Hariri) üzerinden Babilonya'ya vardıkları tahmin edilmektedir. ${ }^{7}$

Başta Akkadça ve Arapça olmak üzere eski ve yeni Samî dillerdeki Orta Asya lehçelerine ait, ancak Samîleştirilmiş, sayısız kelimenin bu dillere girişi kısmen bu karışma döneminde olmuş, kısmen de Sümer bölgesinden Arabistan içlerine göç etmeye mecbur kalan ve buralara yerleşerek Samîleșen Orta Asyalı boyların ana dillerinden kalmıştır. ${ }^{8}$

Samî kavimlerin konuştukları diller, büyük lehçe farklarına rağmen, dilbilgisi kuralları açısından aynıdır. Sami kavimler, Doğu Samîleri ve Batı Samîleri olarak iki büyük gruba ayrılırlar. Doğu Samîlerinin en eski temsilcisi Akkadlar'dır.'

Kaynaklardan anlaşıldığına göre, Sami kavimlerin başlangıçta yüksek bir kültüre sahip olmadıkları görülmektedir. Aksine daha önceleri oldukça ilkel bir göçebe hayatı yaşamakta idiler. Yüksek kültüre işaret eden kavramlar, Samîler'in Mezopotamya ve Suriye'nin medeni unsurları ile karışıp kaynaştıkları devirlere aittir. Tüm bunlar Samî kavimlerin dili, dini, siyasi yaşamları ve medeniyetleri göz önüne alındığında bunların aslında bir çöl halkı olduklarını göstermektedir.

Başka bir görüşe göre Samîler'in kökeni Suriye-Filistin bölgesinde aranmalıdır. ${ }^{10}$ Fakat bu görüş bilim adamları tarafından pek kabul görmemiştir.

Son yıllarda Mezopotamya ve Suriye'de yapılan araştırmalar, Samîler'in buralarda görünüşlerinin tarihi devirlerde olduğunu ortaya koymuştur. Bugüne kadar bilim adamları farklı yerleri Samîler'in ana yurdu olarak kabul etmişlerdir. Bazıları Samîler'in ana yurdunu Suriye'de ve Mezopotamya'da aramıştır. Hatta Samîler'in kökenini Orta Asya'ya kadar götürenler de olmuştur.

Biz ise, bulunan arkeolojik belgelerin 1şığında ve yapılan tarih araştırmaları neticesinde saf Samî tipinin Arabistan'da bulunduğunu düşünmekteyiz.

MÖ. 3. Binyıl başlarında Arabistan'dan Mezopotamya'ya taşan Samî dalgası Suriye ve Filistin'de ancak MÖ. 2500 yıllarına doğru görülmüştür.

\footnotetext{
${ }^{7}$ Kinal 1983, 16.

${ }^{8}$ Günaltay 1987a, 282.

${ }^{9}$ Kinal 1983, 16.

${ }^{10}$ Günaltay 1987a, 284.
} 
Bölgede ilk görünen Samîler sonraları Mezopotamya'da I.Babil İmparatorluğu'nu kurmuş olan Amurrular'dır. Amurrular, Sümer (Sinear) kültürünün etkisinde bulunan bölgede, güneyden gelen yeni göçlerle çoğalmışlardır. Bununla birlikte, medeniyet bakımından da ilerlemeye başlamış, yerli halk ile karışıp kaynaşmışlardır. ${ }^{11}$

İşgal ettikleri bölge boyunca farklı Sami gruplarının nasıl bir dağılım gösterdiğine dair yorum yapmak için elimizdeki bilgiler yetersizdir. Amurrular'ın da bağlı olduğu Sami grubunun tasnifi konusunda farklı görüşler vardır. Genel kabule göre temel kategoriler şunlardır:

\section{Doğu Samiler}

(Akkadlar, Asurlular ve Babilliler )

Batı Samiler

Kuzeybatı Samiler Güneybatı Samiler

(Amurrular, Kenanl1lar, İbraniler, (Kuzey Araplar, Güney Araplar

Aramiler, Fenikeliler) Etiyopyalılar)

Bu tasnif Amurrular'ın bir taraftan İbranilerle, diğer taraftan Araplarla olan ilişkisini gösterir. Amurrular'ın Mezopotamya'ya Arabistan'dan geldiği dikkate alınırsa böyle bir ilişki tabi ki olabilir. Linguistik açıdan bakıldığında bu ilişkinin varlığını iddia etmek çok güçtür. Kültürel açıdan bakıldığında farklar daha da göze batar. Bu gerçekler ışığında 3 semitik grubun olduğu bir sinıflama yapmak mümkündür:

\section{Doğu Samiler}

\section{Batı Samiler}

\section{Güney Samiler}

Hem tarihi hem de tarih öncesi dönemlerle uygun olması açısından bu siniflandırma daha uygundur. ${ }^{12}$

Modern Antropologlara göre çok az bir karışımla homojen bir yapı arz ederler. Eski bir sami ırkının saf halefleri olarak kabul edilirler. Onlar uzun yüzlü, koyu tenli, kısa, küçük ve düz burunludurlar.

$\mathrm{Bu}$ özellikler klasik bir Arap tipidir. Çok fazla işgale uğramamış topraklardaki bu Arap tipolojisi binyıllar boyunca çok az bir değişikliğe uğramıştır. Hatta Mezopotamya'yı Samiler'in vatanı yapan kabul doğru olsa

${ }^{11}$ Günaltay, 1987b, 34-35

${ }^{12}$ Haldar 1971, 2. 
bile kendi topraklarında yaşayan Araplar muhtemelen en saf örneği gösterirler.

Amurru fizyonomisine dair bilgimizi Mısır kaynaklarına borçluyuz. Mısır kaynakları, bu konuda çok önemli bilgiler vermektedir. Bu anıtlardaki karakteristiklere bakarak erken dönemlerden itibaren Akdeniz boyunca yaşamış olan ırkların bir karışımı olan Amurru ırkına mensup kimselerin geniş omuzları vardı ve uzun boyluydular. Başları geniş ve uzundu. ${ }^{13}$

Dilleri semitik bir dildi. Şurası kesindir ki bölgede birçok semitik olmayan dil olsa bile baskın dil grubu onların dili idi. Bu durum kişi isimlerine ve coğrafi isimlere bakılarak görülebilir. Aslında erken Amurru diline ait bilgiler isimlere dayanır. ${ }^{14}$

Amurru bölgesi boyunca geniş bir kullanım alanı bulan Akkad dili İbranice ve Aramice üzerine etkili olmuştur. Suriye'de kullanılan dilin daha sonra Arabistan'a taşınıp şu an bizim Arapça olarak bildiğimiz bir kaynaktan $\mathrm{m}$ çıktıkları cevaplanmayı bekleyen bir sorudur. ${ }^{15}$

Babil'in Batı ve Kuzeybatısında Frrat'ın ötesinde Kuzey Arabistan ve Suriye çölleri yer alır. Buralar step bölgelerdir ve bölgede su sıkıntısı mevcuttur. ${ }^{16}$ Arap Yarımadası'ndaki kuraklık dönemi başladıktan bir müddet sonra 1rmaklar kurumuş, iklim değişmiş, toprak çoraklaşmış, hayat şartları her geçen gün güçleşmiştir. Gittikçe çölleşen Arabistan artık, eski devirlerde her geçen gün artan nüfusu besleyemez hale gelmiştir. Kuraklık ve bunun neticesi olan kıtlık yüzünden, MÖ. 4. Binyılın sonlarından başlayarak Arabistan Yarımadası'nın merkezinden çevresine doğru çeşitli göç hareketleri görülmeye başlamıştır. ${ }^{17}$

Eski Mezopotamya tarihinde üç büyük Samî Göç hareketi görülür. En güçlü ve devamlı göç dalgası kuzeye doğru olmuştur. Kuzeye doğru gerçekleşen ilk göç hareketleri tarihte derin izler bırakmıştır.

Birinci büyük Samî Göçü, MÖ. 3. Binyıl başlarına kadar geriye giden ve M.Ö. 2500'lerde daha da yoğunlaştığ tahmin edilen Akkadlar'ın göçüdür.

MÖ. 3. Binyıl sonları ile 2. Binyıl başlarında meydana gelen ikinci Samî göçü ise Martu ya da Amurru göçleridir. ${ }^{18}$ Amurrular aslında 3.

\footnotetext{
${ }^{13}$ Clay $1919,58$.

${ }^{14}$ Clay 1919, 61.

${ }^{15}$ Clay $1919,62$.

${ }^{16}$ Saggs 2000, 91.

${ }^{17}$ Günaltay 1987a, 285.

${ }^{18}$ Kinal 1983, 18.
} 
Binyılda Mezopotamya'ya asker ve işçi olarak gelmişler ancak 2. Binyılın başlarında siyasi olarak da egemen olmuşlardır. ${ }^{19}$

Amurrular, İbraniler ve Fenikeliler gibi, Samî dillerin doğu lehçesini konuşuyorlardı. Bu nedenle bazı bilginler Amurrular'ı "Doğu Kenanlılar" olarak da adlandırmışlardır.

Amurrular'ın kendi isimlerini kullanmaları, onların Babil'de asimile edilmemiş bir dil yapılarının olduğunu gösterir. ${ }^{20}$

Yakın zamanlarda ele geçirilen bir tablet Eldeki tabletlerse hem Batı Sami isimlerini alan, hem de Amurru isimlerini taşıyan kişileri listelemekle bize III. Ur dönemi ile Eski Babil devri arasında bir bağlantı olduğunu göstermektedir. Demek oluyor ki, III. Ur Sülalesi ile Eski Babil devri Batı Samileri, adı Amurrular olan aynı etnik gruba mensuptular. Hatta şunu söyleyebiliriz ki, bu tabletler bundan 40 y1l önce bilinse idi, Doğu Kenanlılar kavramı akademik çevrelerce hiç kullanılmayacak ve bunun üzerinde hiç tartışma yapılmayacaktı. ${ }^{21}$

Amurrular Tevrat'ta ise Amoritler olarak geçer. ${ }^{22}$

Üçüncü büyük Samî göçü ise, Ege göçlerinin meydana getirmiş olduğu karışıklıklardan yararlanarak, aralıksız bir sızıntı halinde asırlarca devam eden Arami kabilelerinin göçleridir. ${ }^{23}$

Samîler'in anayurdu meselesi ve bu mesele hakkında ortaya atılan farklı görüşleri ele alıp, Sami göçleri hakkında ana hatlarıyla bilgi verdikten sonra şimdi de çalışmamızın esas konusunu teşkil eden Amurru göçlerini ele almaya çalışalım.

\section{Amurru (Martu) Göçleri}

\subsection{Yeni Sümer Devleti (MÖ. 2060-1960)}

III. Ur Sülalesi'nin kurulmasiyla Mezopotamya'da yeni bir dönem başlamıştır. Bu yeni dönemde Ur-Nammu ve halefleri, yabancı istilasının halk üzerinde oluşturduğu tepkiden yararlanmasını bilmişlerdir. Bu durum onların milli hislerini Sümer memleketinin siyasi birliğini sağlama yolunda kanalize etmelerine neden olmuştur. Sümerliliği canlandırmak için ne gerekiyorsa, hepsini yapmaya çaba sarf etmişlerdir. Bu yüzden, III. Ur Sülalesi'nin kurduğu bu devlete "Yeni Sümer Devleti" denildiği gibi,

${ }^{19}$ Karen Rhea Nemet-Nejat, Daily Life in Ancient Mesopotamia, USA 2002, s. 15

${ }^{20}$ Kinal 1983, 18.

${ }^{21}$ Gelb 1968, 46.

${ }^{22}$ Mansel 1945, 7.

${ }^{23}$ Memiş 2009, 174. 
sülalenin yaşadığı bir asırlık döneme de, Mezopotamya tarihinin "Rönesans Devri” denilmiştir.

$\mathrm{Bu}$ döneme ait vesikalar üzerinde çalışan E.O. Edzard ${ }^{24}$, III.Ur Sülalesi'nin çökmesini üç sebebe bağlamaktadır:

1) Partikülarizma

2) Amurru göçleri

3) Babil-Elam rekabeti

$\mathrm{Bu}$ sebeplere ek olarak, memuriyetlerin dağıtılmasında kayırmalar, memleket halkının tek bir kavimden ibaret olmaması gibi iç huzursuzlukları da bunlara ilave etmek gerekir. Her şeyden önce Er Sülaleler Devri'nden beri devam eden bölgecilik zihniyeti, her şehrin yalnız kendini düşünmesi, milli birliğe zarar veriyordu. Akkadlar devrinden sonra bu rekabet, SümerlilikAkkadlılık şeklini almıştı. Sonraları ise Sümer şehirlerine iş bulmak için gelen Amurrular da bu rekabete dahil olmuştu. ${ }^{25}$

III. Ur döneminde Amurrular Mezopotamya'ya hala yabanciydılar. Ancak geldikleri yer buraya çok uzak değildi. Bilakis bunların geldiği bölge ile Sümer şehirleri arasında direkt bir bağlantı vardır. Amurrularla Sümerler'in arasındaki ilişki zaman zaman barışçıl, zaman zaman düşmanca olmuştur. Ama her durumda sürekli bir ilişki vardır. Kaynaklarda bahsedildiği kadarıyla kökenleriyle ilgili bir takım sonuçlara varılabilir. ${ }^{26}$ Martular kavim adı olarak zikredilmekte ve bu kavimlerin şehirlerde oturmadıkları, özellikle vurgulanmaktadır. Böylece, Sümerce Martu kelimesi "Batı" anlamına geldiği gibi, Martuların da Arabistan Yarımadası'ndan çıkarak ilkin Filistin-Suriye şerit arazisini çölden ayıran dağlar üzerinden Kuzey Suriye'ye geldikleri ve oradan Büyük Frrat Kervan Yolu'nu takip ederek, Mari, Terga, Hana gibi başlıca kervan durak yerlerinden geçerek Mezopotamya'ya ulaştıkları anlaşılmaktadır. $\mathrm{Bu}$ kabilelerin bir kısmı Dicle'yi takip ederek, kuzeye Asur ile Kerkük arasındaki bölgeye de varmışlardı. Elbetteki, daha önce Diyala bölgesini de istila etmişler, hatta bir kısmı Diyala'dan öteye yani İran ve Afganistan'a kadar yayıldıkları gibi, III.Ur Sülalesi'nin çökmesinden sonra bilhassa Larsa hakimiyetinden sonra Deniz-eli bölgesine de yerleşecekler ve burada II. Babil Sülalesi'ni (MÖ.1677-1308) kuracaklardır. ${ }^{27}$ Bunu destekleyen temel argümanlar

\footnotetext{
${ }^{24}$ Ayrıntılı bilgi için bkz:D.O. Edzard, Die Zweite Zwischenzeit, Wiesbaden, 1957.

${ }^{25}$ Memiş 2007, 87.

${ }^{26}$ Buccellati 1966, 235.

${ }^{27}$ Memiș 2007, 90.
} 
şunlardır: Birincisi Amurrular'ın dili Batı Sami bir dildir. ${ }^{28}$ Bunların coğrafya ve kabile isimlerinin batı temelli olması ve Mezopotamya'dan bakıldığında Martu teriminin batı için kullanılmasıdır. ${ }^{29}$ Asi ve Fırat'la çevrilmiş olan kurak bölge yarı göçebe bir yaşam tarzı için gayet uygundu. $\mathrm{Ve}$ bundan dolayı Amurrular burada yaşıyordu. $\mathrm{Bu}$ yüzdendir ki, bu bölgeden Dicle'nin kuzeyine geçmek kolay oldu ki, bu geçişin benzerleri daha sonraki dönemlerde de görülmüştür. ${ }^{30}$

Ur'un yıkılışı o zamanki dünyada büyük yankılar uyandırmıştır. Çünkü birçok vesikada bu olay sene ismi olarak kullanılmıştır. Bu nedenle Mezopotamya'da ilk kültür meşalesini yakan Sümerler, Ur'un yıkılmasından ve Yeni Sümer Devleti'nin çökmesinden sonra bir daha devlet kuramayacaklardı. Zaten ana dillerini kaybetmişlerdi.

III. Ur Sülalesi'nin yıkılmasından, Elam'dan sonra en çok istifade eden kavimler, Amurrular olmuştu. Bu ana-baba günlerinde, gittikçe büyüyen bir çı̆̆ gibi, çöl çocukları Mezopotamya şehirlerine doluşmuşlardır. ${ }^{31}$

Yeni Sümer devletinin yıkılmasından sonra Babilonya'da Amurrular, edebiyatlarında Akkadça ve Sümerce kullanımı da dahil var olan kültürü tamamen benimsediler. Hiçbir yerde Amurru dili resmi dil olarak kullanılmadı. Birçok yerde Akkadça konuşuluyor ve yazılıyordu. ${ }^{32}$ Bunun yanında birçok şehirde Amurrular kendilerine has kültür oluşturmaya da başlamıştı. ${ }^{33}$

\subsection{Amurrular ve Amurrular Dönemine Ait Kaynaklar}

Daha önce de ifade ettiğimiz gibi, MÖ. 3. Binyıl'ın sonları ile 2. Binyıl'ın başlarında Mezopotamya, ikinci bir Samî göç hareketine sahne olmuştur. $\mathrm{Bu}$ göç sonunda gelenlere Martular ya da Amurrular denilmektedir. Yaygın kanaat, Amurru Samileri'nin MÖ. 3. Binyıl ortalarında ve daha sonra Arabistan'dan ve Kuzey Suriye'nin çöl bölgelerinden $^{34}$ barbarlar olarak çıktıkları yönündedir. Amurru medeniyetinin Babil kadar eskilere gittiği ve Amurrular'ın Babil'i

\footnotetext{
${ }^{28}$ Gwendolyn Leick, The Babylonians (An Introduction), USA 2007, s. 30

${ }^{29}$ Buccellati 1966, 235-236.

${ }^{30}$ Buccellati 1966, 250.

${ }^{31}$ Kinal 1983, 98.

32 Mieroop 2007, 90; Amuurular'ın dili için ayrıca bkz: A. Leo Oppenheim, Ancient Mesopotamia Portrait of a Dead Civilization, USA 1977, s. 400; Michael Roaf, Cultural Atlas of Mesopotamia and The Ancient Near East, USA 2004, s. 108; Dennis Pardee, "Ugaritic", The Cambridge Encyclopedia of The World's Ancient Languages Ed. Roger D. Woodard, USA 2005, s. 288

${ }^{33}$ Ayrıntılı bigi için bkz: Arnold 2005, 9.

${ }^{34}$ C. Leonard Woolley, The Sumerians, USA 1965, s. 4
} 
güçlendirdiği bilgileri, büyük ölçüde Sümerce ve Akkadça metinlere dayanır. $^{35}$ Amurrular, Babil kentini ele geçirip I. Babil Sülalesi'ni (MÖ.1850-1550) kurmuşlar ve kendilerinden önce Mezopotamya sitelerinde var olan Sümer kültürünü de büyük ölçüde benimsemişlerdir. ${ }^{36}$ Çöllerde göçebe bir hayat yaşayan bu göçebe kabileler, MÖ. 3. Binyıl'ın sonlarından itibaren Mezopotamya'nın bayındır şehirlerine girmeye başlamışlardı. Bu nedenle nüfus artmış, üretici sınıf aynı kalırken, tüketici sınıf birden bire kabarmıştı. Bu dönemde, Mezopotamya'ya hâkim olan III. Ur Sülalesi (MÖ.2060-1960) kralları, Sümer şehirlerine Amurrular'ın (Martular) girmesini önlemek için çeşitli tedbirler almışlardı. Örneğin, 4. Kral Şu-Sin zamanının en büyük olayı, "Martu duvarı" adı verilen ve Babilonya denilen Orta Mezopotamya'daki Abgal (Büyük Su) kanalından 26 saat mesafede bir kale duvarının yapılmasıdır. III. Ur Devleti’nin üzerine çöken kara bulutların ilk belirtisini, bu kalenin inşaasında görmek yanlış olmaz. Nitekim, III.Ur sülalesinin son kralı İbbi-Sin'in İsin şehrindeki valisi İşbierra, İbbi-Sin'e göndermiş olduğu bir mesajda: "Düşman Martular'ın ovalara indiğini duydum" diyerek, tehlikeyi haber veriyordu. İbbi-Sin, tahtta ancak 15 yil kalabilmiş (MÖ.1975-1960) ve devlet, başta Amurru göçleri olmak üzere, partikülarizma ve Babil-Elam rekabeti yüzünden yıkılıp gitmişti. ${ }^{37}$

Yeni Sümer Devleti'nin çökmesindeki en önemli nedenlerinden biri de, Amurru göçleridir. ${ }^{38}$ Nitekim çağdaş bir Eşnunna vesikasında: “íbbi-Sin'in toprakları Martular tarafindan çöl haline getirildi." denilmektedir. Martular'ın ırki kimliklerini tespit edebilmek için, onların dillerini bilmek gerekmektedir. Halbuki Martular'ın dili ile yazılmış hiçbir vesika yoktur. Çünkü bu kavimler kültür memleketlerine girdikten sonra, o memleketin dilini ve yazısını kullanıyorlardı. Ancak, vesikalarda geçen Martu tanrı isimleri ile teşkil edilmiş "Theophore" isimler, filolojik tetkikler için önemli malzeme olarak kullanılmaktadır. ${ }^{39}$

Sümerce vesikalarda, "Martu" kelimesi çoğu kez bir rüzgâr yöntemi olarak geçer. Er Sülaleler III devrine (MÖ.ca. 2550-2350) ait taşınmaz malların satış senetlerindeki yön ifadelerinden de Martu kelimesinin, "Batı" anlamına geldiğini daha önce belirtmiştik. ${ }^{40}$ Martu kelimesi hem bir coğrafi terimdir hem de daha sonraları kabile ismi olarak kullanılmıştır. ${ }^{41}$

\footnotetext{
${ }^{35}$ Clay 1919, 18.

${ }^{36}$ Memiş 2006a, 35.

${ }^{37}$ Memiş 2006b, 26-27.

${ }^{38}$ Saggs 2000, 91.

${ }^{39}$ Kinal 1983, 98.

${ }^{40}$ Memiş 2006b, 27.

${ }^{41}$ Oates 2003, 55.
} 
Mesela İbbi-Sin'e ait bir sene isminde "Ur Kralı Ibbi-Sin'in, eskiden beri şehir bilmeyen Martular'ı büyük bir kuvvetle yendiği sene” ibaresi geçmektedir. Burada Martular kavim adı olarak zikredilmekte ve bu kavimlerin şehirlerde oturmadıklarına bilhassa işaret edilmektedir. ${ }^{42}$

Fara'da bulunan ve muhtemelen MÖ. 2600-2500 yıllarına tarihlenen bir tablette Sümerce ad taşıyan bir adam Martu diye tanımlanmıştır. Bu tanımlamanın bizim açımızdan önemi, çivi yazılı metinlerde Martu'nun en erken kullanılışını bize gösteriyor olmasıdır. ${ }^{43}$

III. Ur sülalesinin son günlerine ait vesikalar ve Mari mektupları Martu kabilelerine karşı yapılan amansız mücadeleyi aksettirirler. Meselâ, I. ŞamşiAdad Terqalı Amurrular'dan olduğu halde, Martu bedevileri ile savaştı̆̆ gibi, yerleşik Martu boyları arasında da savaşlar oluyordu. Aynı suretle Amurru asıllı I. Babil sülalesinin ünlü kralı Hammurabi, kendisi gibi yerleşik Martu asıllı Larsa Kralı Rim-Sin'le ve Mari Kralı Zimri-Lim'le savaşmıştı.

Babiller ise Martular'a "Amurrum" diyorlard1. Örneğin, Akkad krallarından Şarkali-Şarri bir vesikasında: "Başar dağlarındaki Amurrular'a karşı savaştı̆̆ını" bildiriyordu. Bu dağların Palmir ile Fırat arasındaki Cebel Bişri (Bişri Dağları) olduğu zannediliyor. ${ }^{44}$

Samîler ise Martular'a "Amurru” diyorlard1. Martular hakkındaki bütün bu kayıtlardan açıkça anlaş1lıyor ki, bizim bugün bedevi, yani göçebe dediğimiz çöllerde yaşayan kabilelere Sümerler, "Batıdan gelenler" anlamına Martular ismini vermişlerdi. Fakat vesikalardaki bu açıklığa rağmen, Martular'ın vatanı olarak Yukarı Dicle ve Zağros Dağları arasındaki İamutbal memleketini gösterenler de vardır. Bunların iddiası aslen bir Martulu olduğu halde Elamca isim almıș olan Kudur-Mabuk'un unvanları arasında "Atta-KUR.MAR.TU" ve "Atta İamutbal" adlarının bulunmasina dayanır. Aslında bu ünvanlar, Kudur-Mabuk'un ataları tarafindan da kullanılmış olmalıdır. Mezopotamya tarihinde daha sonraları böyle birçok Martu kabilesinin kuzeye, güneye ve doğuya yerleştiklerini görüyoruz. Örneğin, tarihi bir Sümer şehri olan Uruk'a Amanum kabileleri yerleşmişti. ${ }^{45}$

Eğer insanlar topluca bir yerden bir yere gittilerse bunu gösteren bir delil vardır. Fetihlerden, işgallerden, kuşatmalardan bahseden bir delil yoksa bizi bu konuda en iyi isimler aydınlatır. Eldeki Antik Arap medeniyetine dair unsurlara bakarsak, Amurrular'ın, Hititler'in ve Kassitler'in yaptığ 1 gibi bu medeniyetin de insanların göç etmesi suretiyle geldiğini düşünmeliyiz. Bu

\footnotetext{
${ }^{42}$ Kinal 1983, 98.

${ }^{43}$ Sasson 2006, 1234.

${ }^{44}$ Kinal 1983, 99.

${ }^{45}$ Memiş 2006b, 29.
} 
durumda da Arap denilen toplumların hangi ölçüde bu topraklara taşındığını araştırmalıyız.

$\mathrm{Bu}$ toprakların erken tarihine dair efsanelerde ve Babilonya metinlerinde bir kanıt aramak için şunu not etmeliyiz ki Kalde'nin tufan sonrası krallığına ait efsanevi liste bu isimlerin Amurru olduğunu gösterir. Erken hanedan listeleri de aynısını gösterir. Adak metinlerinde, dini metinlerde, kitabeler üzerinde ve tabletler üzerindeki mühürlerde karakteristik olarak Arapça birşey aramak boşunadır, anlamsızdır. Diğer yandan tarihi en az Babilonya kadar eski olan Amurru etkisi en erken tarih kayıtlarında bile görünür. ${ }^{46}$

Şunu belirtmek gerekir Ur'un son krallarıla İsin'in ilk kralları arasında net bir tarihi devamlılık ve örtüşme vardır. Özellikle belirtmek gerekir ki İsin döneminde birçok Amurru bu karşılaştırma sonucunda tespit edilebilmiştir. Ayrıca III. Ur Sülalesi ile I. İsin Sülalesi dönemindeki metinlerde hemen hiç fark yoktur. Hem dil hem de yapı aynıdır. III. Ur döneminden sonra Martu unvanını çok seyrek görürüz.

Amurru terimi Amurrum'a işaret eder ki III. Ur dönemi metinlerinde biz bu kavramı Martu olarak görüyoruz. ${ }^{47}$

Martu bedevileri acaba neden göçüyorlardı? Bu soruyu cevaplamak için, bugünün bedevileri üzerinde yapılan etnolojik tetkiklere bakmak gerekir. Bu kabileler Akkadça Abum (baba) denilen bir şeyhin idaresi altında yaşıyorlar ve besledikleri koyun, keçi ve develerini bir vahadan diğerine otlatarak dolaşıyorlardı. Bu vaha arama veya seçme işi mevsime ve yerleşik kentlerdeki Panayır zamanına ve günlerine göre ayarlanıyordu. Bedeviler ihtiyaçları olan gem, çıngırak vb. her hangi bir aracı hayvanlarının ürünü karşılığında bu pazarlardan temin ediyorlardı. Onlar için şehir hayatı dayanılmaz bir esaretti. Orada herkes hayatını kazanmak için çalışmaya mecburdu. Bu şartlar altında bedevilerin şehirlere dolmaları keyfiyeti, ancak bir açlık, kıtlık veya başka bir bedevi kabile tarafından vahadan uzaklaştırılma gibi bir zorunlulukla meydana geliyordu. Böylece bütün kabile göç ediyordu. Bazen de kabile reisi, bir şehir kralı ile anlaşıyor, bütün kabilesi ücretli asker olarak o şehir kralının emrine giriyorlardı. Bunun en yakın örneği, Birinci dünya savaşında Osmanlı İmparatorluğu ile İngiliz İmparatorluğu mücadelesindeki Suriye savaşlarında görülür.

İşte MÖ. 3. Binyıl'ın sonlarında meydana gelen Amurru (Martu) göçleri yakın zamanlarda da görülen çöl bedevilerinin hareketleri ile hemen hemen aynı idi.

\footnotetext{
${ }^{46}$ Clay 1919, 35.

${ }^{47}$ Buccellati 1966, 10-11.
} 
MÖ. 3. Binyıl'ın sonlarına doğru meydana gelen Amurru göçlerine katılan kavimler hakkında bize en iyi bilgiyi Mari mektupları verir. Çünkü, Mari arşivi vesikalarında, Tevrat'ta da adı geçen Benyamin oğullarından "Maru İamina" yani "Güney oğullart" anlamına bahsedildiği gibi, İbraniler'den de Habirular olarak söz edilir. Ayrıca, Hanalılar denilen başka bir kabile daha vardı. Hanalılar, daha ziyade ücretli askerler olarak görülürler. ${ }^{48}$ Akkadlı Sargon'un zamanında Amurru grupları Mezopotamya'ya sızmaya başladılar. III. Ur döneminde ise bu sızmalar savaşlar halini aldı ve I. Babil Hanedanlığının kurulmasından öncesine denk gelen büyük göçleri doğurdu. ${ }^{49}$ Ortaya ilk çıkışları III. Ur Hanedanının sonundan itibarendir. Ancak isimleri üzerinde yapılan araştırmaya bakılacak olursa bunlar Babil'de küçük bir azınlık olarak kalmıştı. Ne var ki Mari'de çoğunluğu oluşturmuşlardı. Bunların orijinleri ya da kökenleri konusuna gelince; Kupper ${ }^{50}$, göçebe olduklarını ve Suriye steplerinden çıktıklarını söyler. Amurru isimleri bunlar hakkında genel isim olmuştur. ${ }^{51}$

Mezopotamya tarihinde İbbi'sin'in iktidarının devrilmesiyle bir asır süren karanlık bir çağ başlamıştır. Bu karanlık dönemde Amurrular; Larsa, Kis, Babil, Sippar, ve Uruk gibi şehirlerin kontrolünü kesin olarak ele geçirdiler ve halkın büyük çoğunluğu Amurru isimleri taşıyordu. ${ }^{52}$

$\mathrm{Bu}$ şehir krallıkları iki yüzyıldan fazla bir zaman içinde birbirleriyle sürekli savaşacaklar ve bu yüzden de büyük bir devlet kuramayacaklardı. Bu şehir devletleri arasında gerek sürekli egemen olmaları gerekse bıraktıkları vesikalarla III. Ur Sülalesi zamanındaki kültürü yaşatmaları bakımından İsin ve Larsa şehirleri çok fazla varlık göstermişlerdir. Bunun için III. Ur Sülalesi'nin çökmesini takip eden iki asırlık zamana İsin-Larsa devri denilmiştir. $^{53}$

Amurru asıllı şehir beylerinin, MÖ.1960-1750 yı1ları arasına rastlayan iki asırlık dönemde birbirleriyle yaptıkları kıyasıya mücadeleden sonra, I. Babil Sülalesi'nin 6. Kralı Hammurabi, MÖ. 1750'lerde merkezi bir devlet kurarak bu mücadeleye son vermiştir. ${ }^{54}$

\footnotetext{
${ }^{48}$ Kinal 1983, 100.

${ }^{49}$ Kenyon 1963, 8.

${ }^{50}$ Ayrıntılı bilgi için bkz: J. Kupper, Les Nomades en Mesopotamie Tmeps des Rois de Mari, Paris 1957.

${ }^{51}$ Miscellenea 1958, 142.

${ }^{52}$ Sasson 2006, 1234-1235.

${ }^{53}$ Kinal 1983, 100

${ }^{54}$ Memiş 2006b, 30.
} 


\section{Filistin ve Suriye'de Amurrular}

Amurrular'ın sadece Mezopotamya'da değil, Suriye ve Filistin bölgesinde de bir takım şehir devletleri vücuda getirdiklerini Eski Babil dönemi kaynaklarından öğreniyoruz. ${ }^{55}$

MÖ. 17. yüzyıldan itibaren Suriye'de Yamhad krallarının egemen olduklarını ve Hitit kralı I. Hattuşili ile halefi I. Murşili'nin Halep merkezli Yamhad krallığını egemenlikleri altına almak için büyük çabalar sarf ettiklerini Hitit kaynaklarından takip edebiliyoruz.

Eski Önasya'nın karanlık çağında bugünkü Güneydoğu Anadolu Bölgesi'nin bir kısmını egemenlikleri altına alan Mitanniler, Hitit kralı I. Şuppiluliuma tarafindan mağlup edildikten sonra Kuzey Suriye bölgesinin hakimiyeti tekrardan Hititler'e geçti.

MÖ. 1400-1350 yılları arasına tarihlenen Amarna çağında Kuzey Suriye'deki Amurru krallığı saf Amurrular'ın yaşadığı bir şehir devleti idi ve bu devletin hayatiyeti ticarete ve ticari ilişkilerine bağlıydı. Bu devletin ticari ilişkilerini sağlıklı yürütebilmesi ise bölgedeki devletlerle iyi ilişkiler kurmasına ve onları tatmin etmesine bağlıydı.Nitekim, bütün Kuzey Suriye şehir devletleri gibi, Amurru Krallığ da, bu bölgede zamanla değişen büyük bir gücün hakimiyetini kabullenmek zorunda kalmıştır. Doğal olarak bu bağll1ı̆̆ın karşılığı olarak da o devlete çoğu zaman ağır vergiler ödemiştir. Amarna çağında Kuzey Suriye'nin hakimi Hititler olduğu için, Amurru kralları da Hititler'le muhatap olmak ve onların arzularına göre hareket etmek zorunda kaldılar. Gerçekten, Amurru devletinin Amarna çağında iktidara gelen kralları Abdi-Aşirta ve oğlu Aziru'nun Amarna arşivinde bulunan mektupları, bu krallığın, yaşayabilmek için nasıl iki yüzlü bir politika izlediğini bütün çıplaklığı ile ortaya koymaktadır.

Şuppiluliuma, Amurru Krallığı'nı ele geçirdiği zaman Amurru Kralı Aziru ile bugün elimizde bulunan antlaşmayı yapmıştı. Aynı şekilde II. Murşili'nin, Aziru'nun oğlu Duppi-Teşup ile yapmış olduğu antlaşmadan Amurru Devleti'nin isyan etmiş olduğu anlaşılmaktadır. Yine bu antlaşmadan anlaşıldığına göre, Murşili zamanında da Amurru Krallığı, Kinza (Kadeş) ve Nuhaşşe memleketleri ile birlikte iki defa isyan etmiş ise de, Murşili, bunları yeniden itaat altına almayı başarmıştı. Muvattali döneminde, Amurru Devleti'nin tekrar entrikalar çevirmeğe başladığ anlaşılıyor. Çünkü, IV. Tuthalya'nın Amurru Kralı İştarmuva ile yaptığı antlaşmada da "Babası Penteşina'nın Mısır tarafına geçmesi üzerine Mısır

${ }^{55}$ Ayrıntılı bilgi için bkz: Gelb 1961, 44. 
ve Hitit Devletleri'nin harp ettikleri" bildirilmektedir. ${ }^{56}$ Neticede, iki büyük devlet arasinda tampon bir devlet olan Amurru, bir tarafa ihanet etmesi ile savaşın sonucunda etkili olmuştur. ${ }^{57}$

Fenike sahillerindeki şehirlerin bir kısmı yine Amurru kuvvetleri tarafindan ele geçirilmişlerdir. $\mathrm{Bu}$ nedenle Misır hakimiyeti buralarda zayıflamıştır. İşte bu sıralarda, Biblos kralı ve diğer beyler, Mısır'dan yardım istemişlerse de, Kral Akheneton (IV.Amenofis) gerçek anlamda bir yardımda bulunamamıştır. Tel-el-Amarna'da, Fenike beylerinin yardım taleplerini bildiren mektuplar da bulunmuştur. ${ }^{58}$

\section{Babil'de Amurrular}

Amurrular, uzun yıllar Sümer ve Akkad hâkimiyetinde kalarak, aylıklı asker, işçi ve tacir olarak çalıştılar, daha sonra Akkad ilinde toplandılar ve buradaki Samîler'le birleştiler. ${ }^{59} \mathrm{Bu}$ sülâlenin ünlü kanunlarıyla tanınan altıncı kralı Hammurabi (MÖ. 1750'lerde), Sümer kentlerini ve Akkad ülkelerini tek bir yönetim altında birleştirmiştir. Hammurabi'nin kurduğu bu yeni düzenin, teokratik bir devlet olmaktan çok dünyevî bir devlet olduğu genellikle kabul görmektedir. Bu devlet, Akkad İmparatorluğu gibi büyük bir dünya devleti olmayıp, memurların yönetimine dayalı milli bir devlettir. Babil kenti, devletin başkenti yapılmış ve bundan sonra kurulan Babil devletlerinin de merkezi olmuştur. ${ }^{60}$

Hammurabi dönemi, Eski Babil'in doruk noktası olmuştur. $\mathrm{Bu}$ dönemde, Sümer, Akkad, Elam, Gutiler ve Amurrular'ın bir araya gelmeleri sonucu oluşan ırklar karışımında, küçük bir azınlık durumuna düşen Sümerler, zamanla Samîler içerisinde eriyip gitmişlerdir.

İyi bir komutan ve idareci olan Hammurabi bütün gücüyle Mezopotamya'yı Samîleştirdi. Babil kültürünü Mezopotamya kültürü durumuna getiren bu kralın döneminde görülen siyasal ve sosyal alandaki çalışmalarla ilgili yazılı belgelerin çokluğu bilimsel açıdan geniş bir bilgi birikimi sağlamaktadır. ${ }^{61}$

Hammurabi, Mari bölgeleri ile Asur ili de dahil olmak üzere bütün Subaru'yu, Elam'ı, aşağı denizden Amurru'ya ve yukarı denize kadar olan ülkeleri ele geçirmişti. Büyük Akkad Devleti'ni yeniden canlandırmıştı. Bu

\footnotetext{
${ }^{56}$ Memiş 2009, 122.

${ }^{57}$ İnan 1987, 115.

58 İnan 1987, 135.

${ }^{59}$ Yildırım 1996, 35.

${ }^{60}$ Memiș 2009, 35.

${ }^{61}$ Yildırım 1996, 35.
} 
büyük başarı kendisine Sümer-Akkad kralı, dört cihan hükümdarl, cihan imparatoru gibi ünvanlar kazandırmıştır. Hammurabi, sonraları bunlara ek olarak Martu Addası yani Amurru atası ünvanını da aldı.

Amurrular'ın bütün Sinear'a hâkim olmaları, büyük tarihi sonuçlar doğurdu. Sümerler, Akkadlar, ElamIar, Guti'ler gibi çeşitli kavimleri barındıran Sinear, yeni gelen Amurru dalgaları ile çeşitli ırkların karışmasına neden oldu. Burada tarihin tanımış olduğu eski medeniyeti kuran Sümerlerle bu medeniyete benzeyen Akkadlar, Elamlar ve Gutiler, yarı bedevi, haşin, yırtıc1, yağmacı ve bilhassa mütevazi bir devletin karışık ve çeşitli özelliklerine sahip olan Amurrular'ın hakimiyeti altına düşmüşlerdi. Eski bir kültüre sahip ve medeni kanunlara uymaya alışkın olan Sinear Siteleri'nin yarı bedevî bir halkın hükmü altına girmesi, beraberinde şu sonuçları getirdi:

1- Sümerler'le Akkad'lar arasinda binlerce seneden beri devam eden rekabet ortadan kalktı.

2- Azınlıkta kalan medeni Sümer milliyeti, Sami dalgaları içinde kayboldu. İstilacıların zulümlerine dayanamayan Sümerlerden bir kısmı da vatanlarını terk ederek, etrafa dağıldılar. Geride kalanlar ise çoğunluk içinde pek bir varlık gösteremediler ve zamanla onlara benzemeye başladılar.

3- Binlerce senelik bir medeniyet meydana getirmiş olan bu kavim, böylelikle tarih sahnesinden çekilmişdi. Ancak, manen asırlarca varlığını sürdürdü.

Öteden beri Sümer-Akkad ili Kalde adıyla anılan Sinear da bu zamandan sonra Amurrular'ın payitahtıyla ilişkili olarak Babilistan adını ald1.

Aynı zamanda Amurru soyundan olan Hammurabi, ${ }^{62}$ bütün Sinear'ı Samîleştirmek için çok çalıştı. Sümer-Akkad illerindeki eski siteler, Babil'in karşısında fazla direnemediler. Bütün bu şehirlerin güzellikleri Babil'de toplandı. Yani Babil başkent oldu. Babil halkının kalabalıklığı, mabetlerinin, saraylarının görkemi yakın şarkın en güzel şehrini oluşturdu. ${ }^{63}$ MÖ. 18. Yüzyıl'da Sümer ve Akkad'ı birleştiren I. Babil Devleti Samî 1rktan olduğu için, krallığın resmi dili de Akkadça idi. ${ }^{64}$

$\mathrm{Bu}$ siyasi yeniliğin derin anlamını anlatabilmek için, dini sahada da bir inkılâp yapıldı. Sami Akkad'lar devrinde bile muhteşem mevkiini

\footnotetext{
${ }^{62}$ Mieroop 2006, 2.

${ }^{63}$ Günaltay 1987a, 513-515.

${ }^{64}$ Memiş 2007, 118.
} 
koruyabilen Sümer'lerin Enlil'i, imparatorluk tapınağı olmak mevkiinden düşürüldü. Ona ait an'anevî ayrıcalıklar Babil tapınağı Marduk'a verildi.

Bu dini inkılâp siyasî inkılâptan daha önemliydi. Akkad krallarından Sargon ve Naram-Sin bile buna cesaret edememiştir. Kendilerine hükümdarlık tacını bahşedenin Enlil olduğunu ve onun vekili sıfatı ile saltanat sürdüklerini ilân etmeye mecbur kalmışlardı. Fakat Sinear üzerinde büyük bir otoriteye sahip olan ve bu gücüne güvenen Hammurabi, böyle bir şeye gerek görmemiştir. Sümer-Akkad unsurları ile beraber Enlil'i de iktidardan atmıştır.

Hammurabi döneminde Amurru İmparatorluğu'nun sinırları, Sargon devrindeki Akkad Devleti sınırlarıyla aynı idi. Amurrular Sümer, Akkad ve Elam illerini zor kullanarak almışlardı. Fakat Suriye ile Filistin'e hâkim olmak için silah gücü kullanmaya mecbur kalmadılar. Bu bölgede çoğunluğu oluşturan ırktaşları, bir şart göstermeksizin Babil kralını tanıdılar.

Hammurabi'den sonra iç isyanlar ve dışardan gelen Kassit saldırıları yüzünden Babil, fazla uzun ömürlü olmamıştır. I. Babil Devleti, Hitit Kralı I. Murşili tarafından MÖ. 1550 'de ortadan kaldırılmış, kentin zenginlikleri yağmalanmış, halkı Dicle boylarına sürülmüştür. ${ }^{65}$ Fakat Hititler'in de bu ülkede uzun süre kalamayışlarından doğan boşluktan yararlanan Kaslar, Babil topraklarına hâkim oldular. ${ }^{66}$ Eski Babil Devleti'nin yerini Kaslar aldıysa da, bunlar da MÖ. 1100'lerde Asurlular tarafından yıkılmışlardır. Daha sonraki yüzyıllarda kurulan Yeni Babil Devleti de, Yunan tarihçisi Herodotos'tan öğrenildiğine göre, MÖ. 539 yılında Persler tarafından ortadan kaldırılmıştır. $^{67}$

\section{SONUÇ}

MÖ. 3. Binyılın sonları ile MÖ. 2. Binyılın başlarında cereyan eden Amurru göçleri sonucunda Eski Önasya tarihinde gerek etnik, gerek siyasal, gerekse kültürel yönlerden önemli değişimler meydana gelmiştir.

Gerçekten bugünkü Araplar'ın en eski ataları olarak kabul edilen bu kavimler, muhtemelen Arabistan Yarımadası'ndaki anavatanlarından yola çıkarak, bereketli Mezopotamya topraklarını işgal etmek suretiyle, hem bu coğrafyada hem de Mezopotamya'ya komşu ülkeler coğrafyasında önemli faaliyetler gerçekleştirmişlerdir.

\footnotetext{
${ }^{65}$ Memiş 2007, 125.

${ }^{66}$ Yildırım 1996, 36.

${ }^{67}$ Memiş 2006a, 36; Ayrıca bkz: Herodotos/Herodot Tarihi, I. Kitap 188-190.
} 
III. Ur sülalesinin çökmesinden kısa bir zaman sonra Mezopotamya sitelerine yayılan Amurrular ya da Martular, çok geçmeden Mezopotamya'yı tam anlamıyla Samî bir hüviyete büründürmüşlerdir. Öyle ki, Amurrulu kabilelerin kurduğu devletler her tarafı kaplarken, Sümer dili de yerini Akkad diline ve yazısına terk etmiştir. Çünkü Amurrular da kendilerinden önceki ataları Akkadlar gibi Akkadça konuşuyor ve Akkad dilinde yazıyorlardı. III. Ur sülalesinin yıkılmasıyla başlayan yeni dönemde eski şehirlerin birçoğu önemini kaybetmiş, buna karşıllk eskiden küçük birer yerleşim merkezi olan yerler büyük birer şehir olmuşlardı. Fırat ve Dicle arasında bulunan Girsu (bugünkü Telloh) ve Lagaş, Umma, Şuruppak, Kiş ve Adab gibi eski devirlerin ünlü Sümer şehirleri, bu yeni devirde yıldızları parlayan İsin ve Larsa şehirlerinin kontrolüne girmişti. III. Ur sülalesinin MÖ. 1960 yılında çökmesinden Babilli Hammurabi tarafından Mezopotamya'da siyasi birliğin yeniden kurulmasına (MÖ. ca. 1750'ler) kadar geçen yaklaşık iki asırlık zaman dilimine İSINN-LARSA devri denilmiştir. Şunu belirtmek gerekir ki, Ur'un son krallarıyla İsin'in ilk kralları arasında net bir tarihi devamlılık ve örtüşme vardır. Özellikle belirtmek gerekir ki İsin döneminde birçok Amurru ismi bu karşılaştırma sonucunda tespit edilebilmiştir. Ayrıca III. Ur Sülalesi ile I. İsin Sülalesi dönemindeki metinler arasında hemen hiç fark yoktur. Hem dil hem de yapı aynıdır. Amurrulu kabilelerin kurduğu önemli siyasi güçlerin bir diğeri de Eski Babil Devleti'dir ki, bu devletin en tanınmış şahsiyeti de kanunları ile ünlenmiş 6. kral Hammurabi'dir. Hammurabi, devletini, büyük bir bürokrasi kadrosuyla yönettiği gibi, 282 maddeden oluşan ve Batı dünyasının çok sonradan akıl ettiği hukuk kurallarını daha MÖ. 1750'lerde taşlara nakşetme başarısını göstermiştir.

Bütün bunlar bize gösteriyor ki, Mezopotamya merkezli Eski Önasya medeniyetinde Samî kavimlerden birisi olan Amurrular'ın rolü ve payı oldukça büyüktür. Mezopotamya medeniyetinin temelleri Sümerler'e aitse, bu yapının duvarları ve çatısında Samî kavimlerin büyük emeği olduğunu unutmamak lâzımdır. Üstelik onlar Sümerlerle başlayan bu medeniyete kendilerinden de yeni şeyler katarak, karmaşık orijinli yeni bir uygarlığın doğmasına da zemin hazırlamışlardır. 


\section{EK:}

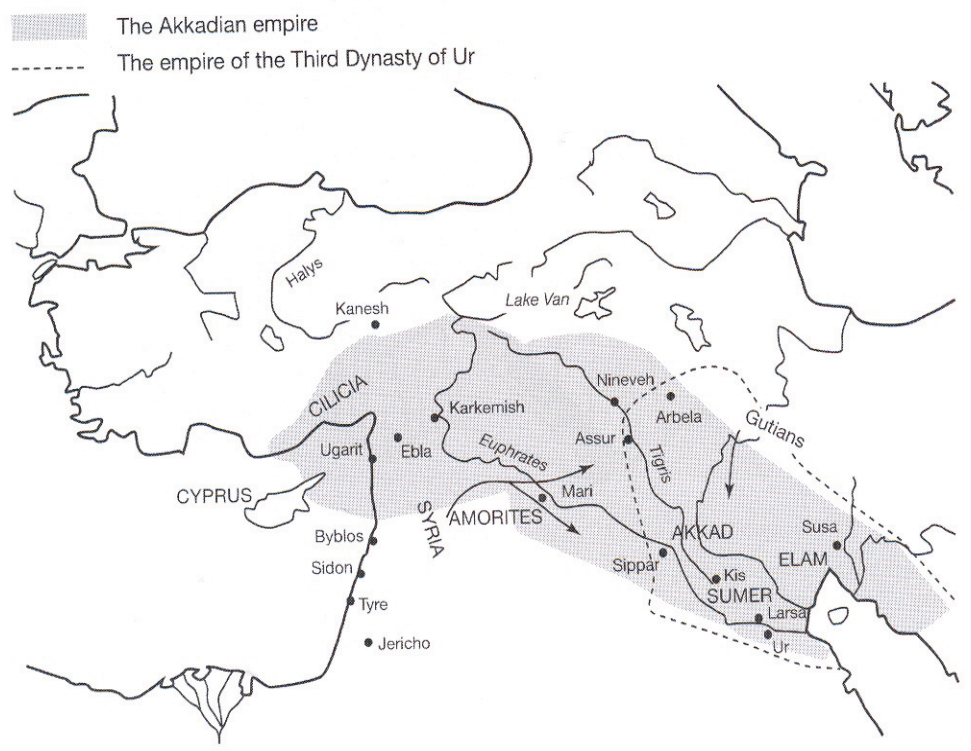

MAP 2.1 The ancient Near East in the third millennium BC

Harita 1. MÖ. 3. Binyılda Eski Yakın Doğu 68

${ }^{68}$ Blois de L, Spek Van Der R. J., 17. 


\section{Kaynakça}

Arnold, T. Bill, 2005. Who Were The Babylonians, Brill, Leiden-Boston.

Blois de L, Spek Van Der R. J, 2008. An Introduction Ancient World, USA.

Buccellati, G1org10, 1966 The Amorites of the Ur III Period, Naples.

Clay, Albert T, 1919. The Empire of The Amorites, Yale University Press, USA.

Edzard, D. O, Die Zweite Zwischenzeit, Wiesbaden, 1957.

Gelb, I.J, 1968. “An Old Babylonian List of Amorites”, JAOS, Vol: 88, s. 39-46.

Gelb, I.J, 1961. "The Early History Of The West Semitic Peoples”, JCS Vol.15, s. 27-47.

Günaltay, M.Ş, 1987a. Türk Tarihinin Illk Devirlerinden Yakın Şark Elâm ve Mezopotamya, T.T.K Basımevi, 2. Bask1, Ankara.

Günaltay, M.Ş, 1987b. Yakın Şark III Suriye-Filistin, T.T.K Basımevi, 2. Baskı, Ankara.

Günbatt1, Cahit, 1997. "Kültepe'den Akadlı Sargon'a Ait Bir Tablet”, Archivum Anatolicum Anadolu Arşivleri (Emin Bilgiç Anı Kitabı), Sayı 3, s. 131-155.

Haldar, Alfred, 1971. Who Were The Amorites, E.J.Brill, Leiden.

Herodotos, 2002. Herodot Tarihi, Çev: Mümtekim Ökmen, Türkiye İș Bankası Kültür Yayınları, İstanbul.

İnan, Afet, 1987. Misır Tarih ve Medeniyeti, 2. Bask1, TTK Yayınları, Ankara.

Kenyon, Kathleen M, 1963. Amorites and Canaanites, The Oxford University Press, London.

Kınal, Füruzan, 1983. Eski Mezopotamya Tarihi, A.Ü.D.T.C.F. Yayınları, Ankara.

Kupper, J, 1957. Les Nomades en Mesopotamie Tmeps des Rois de Mari, Paris.

Leick, Gwendolyn, 2007. The Babylonians (An Introduction), USA

Mansel, Arif Müfit, 1945. Eski Doğu ve Ege Tarihinin Ana Hatlart, İstanbul.

Memiş, Ekrem, 2009. Eskiçağ Türkiye Tarihi, Çizgi Kitabevi, 9. Baskı, Konya.

Memiş, Ekrem, 2007. Eskiçağda Mezopotamya En Eski Çağlardan Asur İmparatorluğunun Yıkılışına Kadar, Ekin Kitabevi, Bursa.

Memiş, Ekrem, 2006a. Eskiçağ Medeniyetleri Tarihi, Ekin Kitabevi, Bursa.

Memiş, Ekrem, 2006b. Memiş, Ekrem, İsrail Nereye Koşuyor? (En Eski Çağlardan Günümüze İsrail-Filistin Mücadelesi), Ekin Kitabevi, Bursa.

Mieroop, Van De Marc, 2006. King Hammurabi of Babylon, Blackwell Publishing, USA.

Mieroop, Van De Marc, 2007. Mieroop, Van De Marc, A History of the Ancient Near East ca. 3000-323, Blackwell Publishing, USA.

Miscellenea 1958. "The Contribution of The Göçebes To The Babylonian Population", JESHO Vol: I, 138-145 E.J.Brill Leiden.

Nemet-Nejat,-Karen Rhea, 2002. Daily Life in Ancient Mesopotamia, USA

Oates, Joan., 2003. Babylon, London.

Oppenheim, A. Leo., 1977. Ancient Mesopotamia Portrait of a Dead Civilization, USA 